\title{
Pitahaya (Hylocereus spp.): a new fruit crop, a market with a future
}

\author{
Fabrice Le BELLEC ${ }^{a^{*}}$, Fabrice VAILLANT ${ }^{b}$, Eric IMBERT ${ }^{c}$
}

${ }^{\text {a }}$ Cirad, UPR Production fruitière, Stn. de Neufchâteau, Capesterre B/E, Guadeloupe, F-97130 France, fabrice.le_bellec@cirad.fr

${ }^{\mathrm{b}}$ Cirad, UPR Qualité des aliments, Cita, Univ. Costa Rica, 2060 San José,

Costa Rica

${ }^{c}$ Cirad, UPR bananes et ananas, Blvd. La Lironde, TA 50 /PS 4,

Montpellier Cedex 5 , F-34398 France

${ }^{*}$ Correspondence and reprints

Received 4 October 2005 Accepted 9 March 2006

Fruits, 2006, vol. 61 , p. $237-250$ (C) 2006 Cirad/EDP Sciences All rights reserved

DOI: 10.1051/fruits:2006021 www.edpsciences.org/fruits

RESUMEN ESPAÑOL, p. 250

\section{Pitahaya (Hylocereus spp.): a new fruit crop, a market with a future.}

Abstract - Introduction. Still practically unknown in the mid-1990s in Europe, pitahaya (Hylocereus spp.) is now a full member of the 'small exotic fruits' category in shops. Nevertheless, these species are not very well known. The aims of our work were first to evaluate thoroughly the literature currently available on Hylocereus and secondly to supplement this review by agronomic works not yet published. Knowledge of Hylocereus. The study includes a presentation of the origin, botany, morphology and floral biology of the principal species cultivated within the Hylocereus genus and suggests a key for determination. Cultivation techniques. The agronomical practices used in Hylocereus orchards are broached: multiplication, cultivation practices (supports, density, pruning, mineral nutrition, irrigation, etc.), pollination and harvest. Pests and diseases are cited too. Physico-chemical composition of fruits. This work draws up a review of different studies regarding pitahaya composition, micronutrients and pigments. Post-harvest and processing. The life of the fruit after harvest (conservation and storage life) is approached as well as the various possibilities of processing. European market. The European market is analyzed for the various cultivated species of Hylocereus (imported quantity, market segment, origin of production, etc.) and its evolution prospects are evoked. Conclusion. Our review highlights the fact that the interest shown in these pitahayas is recent and, for these reasons, more detailed knowledge on these species is required (agronomic, genetic and technological).

tropical zones / subtropical zones / Hylocereus / botany / agronomy / chemical composition / storage / postharvest technology / European union / markets

\section{Les pitahayas (Hylocereus spp.) : nouveaux fruits, marché en devenir.}

Résumé - Introduction. Encore pratiquement inconnues dans le milieu des années 1990, les pitahayas (Hylocereus spp.) font désormais partie intégrante du marché européen au linéaire " petits fruits exotiques". Pourtant, ces différentes espèces semblent mal connues. Les objectifs de notre travail ont été à la fois de faire un point approfondi de la bibliographie disponible et de compléter cette synthèse par des travaux agronomiques non publiés. Connaissance des Hylocereus. L'étude comprend une présentation de l'origine, la botanique, la morphologie et la biologie florale des principales espèces cultivées au sein du genre Hylocereus et propose une clé de détermination. Techniques culturales. Les différentes pratiques culturales connues sont abordées : techniques de multiplication, conduite agronomique (palissage, taille, fertilisation, irrigation, etc.), pollinisation, récolte, etc. Les principaux ravageurs et maladies sont également cités. Composition physico-chimique des fruits. Ce travail fait une synthèse des différentes études effectuées sur la pitahaya : composition physico-chimique, micronutriments et colorants. Postrécolte et transformation. La vie du fruit après récolte (conservation, stockage, etc.) est abordée, ainsi que les différentes possibilités de transformation. Marché européen. Le marché européen est analysé pour les différentes espèces d'Hylocereus cultivées (volumes importés, provenances, etc.) et ses perspectives d'évolution sont évoquées. Conclusion. Notre synthèse bibliographique montre que l'intérêt porté aux pitahayas est récent et qu'il convient, pour ces raisons, d'approfondir les connaissances sur ces espèces (agronomie, génétique, technologie).

zone tropicale / zone subtropicale / Hylocereus / botanique / agronomie / composition chimique / stockage / technologie après récolte / union européenne / marché 


\section{Introduction}

Practically unknown fifteen years ago, pitahaya $^{1}$ today occupies a growing niche in Europe's exotic fruit market $[1,2]$ as well as in the domestic markets of producer countries, such as Vietnam [3], Colombia [1], Mexico [4], Costa Rica and Nicaragua [5]. Elsewhere, pitahaya is considered to be a new, promising fruit species; it is cultivated on different scales in Australia [6], Israel [7] and Reunion Island [8]. This success can be explained in part by the fruit qualities and characteristics (attractive colors and shape) and also by the commercial policies of some producing and exporting countries (e.g., Vietnam, Colombia and Israel).

The generic term 'pitahaya' includes several different species and this can be a source of confusion. Currently, only a few species of pitahaya are usually found on the market: yellow pitahaya [S. megalanthus (Schum.) Britt \& Rose], a fruit with a yellow skin and white pulp, and red pitahaya (Hylocereus spp. Britt \& Rose), fruits with a red skin and white or red pulp, depending on the species. Our study deals more particularly with the genus Hylocereus that comprises sixteen species. These species are endemic to Latin America and, to our knowledge, they are not very well known and have only recently been the subject of studies. Available publications deal with very specific topics associated with the difficulties met by countries that have introduced the new species; the principal research topics being floral biology [7, 9-12] and ecophysiology [13-21]. The aims of our work were to draw up an exhaustive list of literature currently available on Hylocereus, grouping the references by discipline (botany, biogeography, floral biology, agronomy, post-harvesting, composition and marketing) and to complete the list with agronomic works that have not been published in international journals, but are useful for those involved in promoting the new species.

\footnotetext{
${ }^{1}$ Different spellings are used: Pitahaya, pitaya, pitajaya, pitajuia or pitalla.
}

\section{Knowledge of Hylocereus}

\subsection{Botanical classification}

Pitahaya belongs to the genus Hylocereus of the botanical family Cactaceae. Hylocereus is characterized by climbing plants with aerial roots that bear a glabrous berry with large scales [22]. Hylocereus spp. are diploid ( $2 n=$ 22) $[4,10]$. The dicotyledonous family Cactaceae (Caryophyllales) comprises between 120 and 200 genera consisting of between 1500 and 2000 species found especially in the semi-desert, hot tropical regions of Latin America [23]. Cactaceae are mainly appreciated for their ornamental qualities, but they also include nearly 250 cultivated species of fruit-bearing and industrial crops [24]. However, few species are of economic value. The genus Opuntia Mill. is probably the most widely cultivated for its fruits (cactus pear, prickly pear, Barbary fig or tuna) and Dactylopius coccus O. Costa, the host of the cochineal insect from which red dye is extracted [1]. The cochineal insect is also raised on Nopalea cochenillifera (L.) SalmDyck [23].

In Latin America, many different cultivated species and fruits are referred to as pitahaya, a generic and vernacular name that renders their botanical classification difficult. However, all pitahaya are grouped into four main genera: Stenocereus Britton \& Rose, Cereus Mill., Selenicereus (A. Berger) Riccob and Hylocereus Britton \& Rose [1, $25]$. We focused more particularly on the Hylocereus species.

There are many contradictions concerning the botanical classification of Hylocereus $[1,5]$ that are probably explained by the similar morphological characteristics and / or environmental conditions. In our paper, we use the Britton and Rose classification [25] (figure 1), but also took into consideration the results of recent genetic analyses [26]. Thus, there are 16 species of Hylocereus, whose ornamental value is due to the beauty of their large flowers $(15-25 \mathrm{~cm})$ that bloom at night; they are creamy white in color, except $H$. stenopterus and H. extensus whose petals are red and rose pink [27]. Even if all these species can potentially 
produce fruits, only a certain number are cultivated for this purpose and our study was limited to those.

The five species determined by Britton and Rose classification [25] can be more precisely described:

- H.purpusii (Weing.) Britton \& Rose (figure 2) has very large $(25 \mathrm{~cm})$ flowers with margins; outer perianth segments are more or less reddish; middle perianth segments golden, and inner perianth segments white. It presents scarlet, oblong fruit covered with large scales (length: 10-15 cm; weight: 150 $400 \mathrm{~g}$ ); red flesh with many small black seeds; pleasant flesh texture, but not very pronounced. $H$. purpusii is closely related to H. ocamponis (S.D.) Britton \& Rose, the two being distinguished only by the acicular and slender spines of $H$. ocamponis.

- H.polyrbizus (Web.) Britton \& Rose has very long $(25-30 \mathrm{~cm})$ flowers with margins; outer reddish perianth segments, especially at the tips; and rather short and yellowish stigma lobes. Its scarlet fruit (length: 10 $12 \mathrm{~cm}$; weight: 130-350 g) is oblong and covered with scales that vary in size; it has a red flesh with many small black seeds, pleasant flesh texture and good taste. $H$. venezuelensis Britton \& Rose is closely related to $H$. polyrhizus, the only difference being whole (H. polyrhizus) or bifid stigma lobes (H. venezuelensis).

- H. costaricensis (Web.) Britton \& Rose (figure 2) presents vigorous vines, perhaps the stoutest of this genus. Stems are waxywhite and flowers are nearly the same as $H$. polyrhizus; its scarlet fruit (diameter: 10$15 \mathrm{~cm}$; weight: 250-600 g) is ovoid and covered with scales that vary in size; it has a redpurple flesh with many small black seeds, pleasant flesh texture and good taste. A few varieties are known in Costa Rica: 'Lisa', 'Cebra' and 'Rosa' [28].

- H. undatus (Haw.) Britton \& Rose (figure 3) has long and green stems, more or less horny in the age margins. Flowers are very long (up to $29 \mathrm{~cm}$ ), outer perianth segments are green (or yellow-green) and inner perianth segments pure white. Its rosy-red fruit (length: 15-22 cm; weight: 300-800 g) is oblong and covered with large and long scales, red and green at the tips; it has a

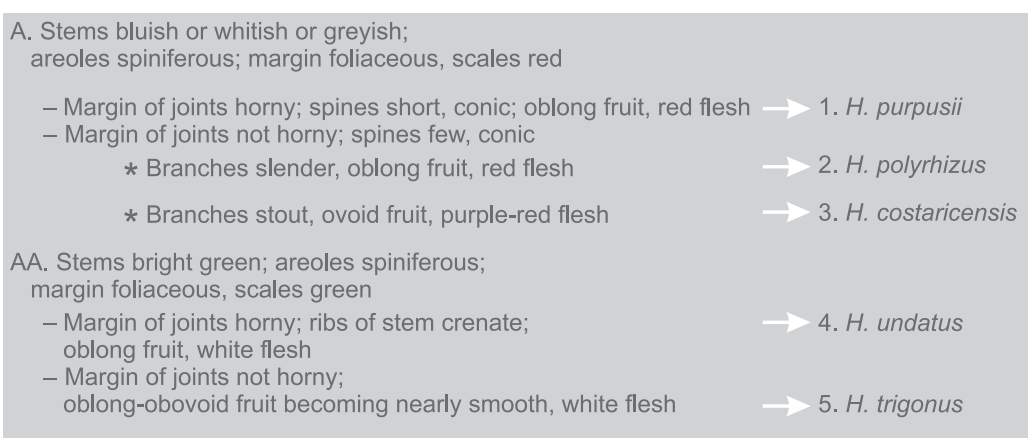

white flesh with many small black seeds, pleasant flesh texture and a good taste.

- H. trigonus (Haw.) Saff. (figures 4, 5) presents slender, green with margins, not horny stems. The areoles are located on the top of the rib's undulation. Spines, at first greenish, soon turn dark brown. Its red fruit (diameter: 7-9 cm; weight: $120-250 \mathrm{~g}$ ) is ovoid or oblong, becoming nearly smooth;

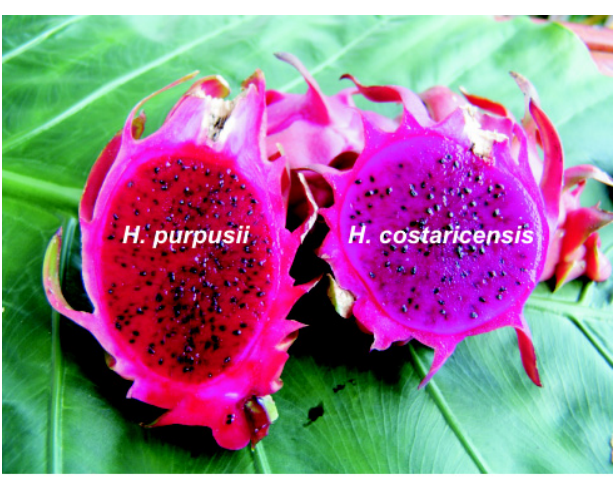

Figure 1.

Key to species of the genus Hylocereus according to

Britton and Rose classification [25]: ovary and red, rose-pink or scarlet fruit are covered with large foliaceous scales, their axils are neither spiny, hairy, nor bristly; flowers are very large, nocturnal; stems are 3-angled or 3-winged.

Figure 2.

Fruits of Hylocereus sp. (A color version of this figure is available at www.edpsciences.org/fruits.)

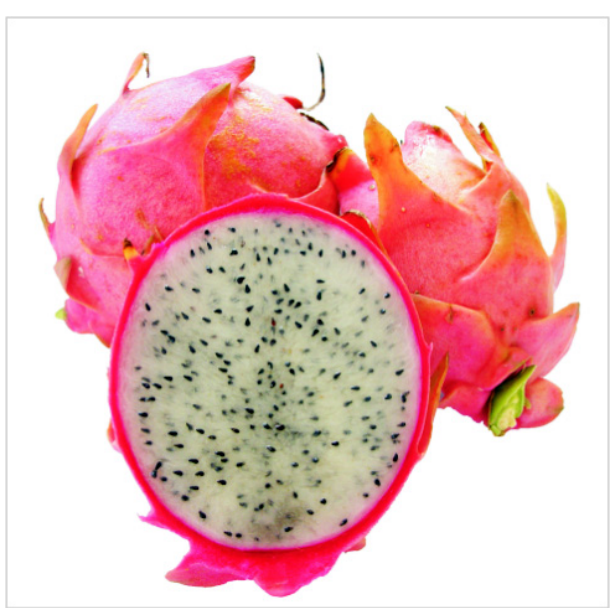

Figure 3.

Fruit of Hylocereus undatus. (A color version of this figure is available at www.edpsciences.org/fruits.) 
Figure 4.

Fruit of Hylocereus trigonus. (A color version of this figure is available at www.edpsciences.org/fruits.)

Figure 5.

Plant of Hylocereus trigonus in French West Indies.

(A color version of this figure is available at www.edpsciences.org/fruits.)
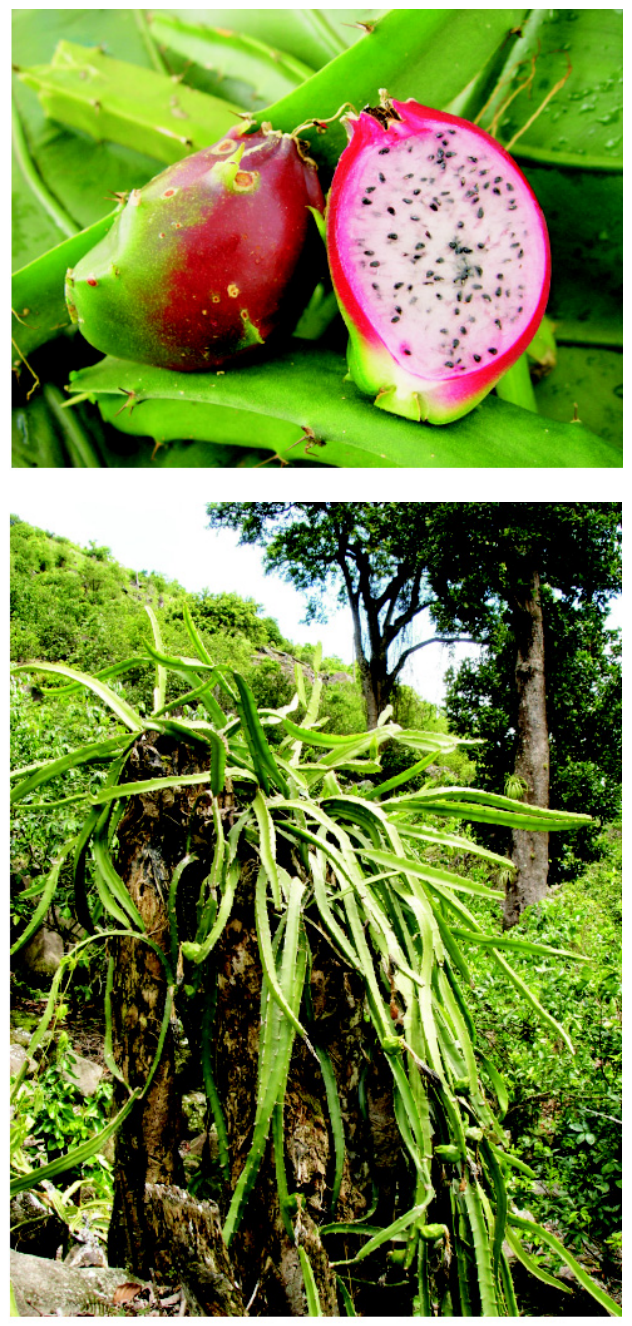

the white flesh has many small black seeds and pleasant flesh texture, but not a very pronounced flavor.

\subsection{Origin, distribution and ecology of Hylocereus}

Most Hylocereus species originate principally from Latin America (probably from Mexico and Colombia), with others possibly from the West Indies [25, 29]. Today they are distributed all over the world (in tropical and subtropical regions), but H. undatus is the most cosmopolitan species.

In their original region, the fruits of Hylocereus sp. are the main traditional fruit and the most widely consumed local fruit [1,
$4,5,24]$. These fruits are rarely cultivated on a large scale outside Colombia, Costa Rica and Nicaragua [30]. However, in Vietnam, $H$. undatus has undergone extensive development with nearly 2000 ha under cultivation [3]. Elsewhere, pitahayas are considered a new fruit with a promising future and are cultivated on quite a large scale in Australia [6], Israel [7] and Reunion Island [8].

The robustness of Hylocereus species enables them to prosper under different ecological conditions. For example, in Mexico, they are found in very rainy regions [(340 to 3500$) \mathrm{mm} \cdot \mathrm{year}^{-1}$ ] and at altitudes of up to $2750 \mathrm{~m}$ above sea level [4]. They can survive in very hot climates, with temperatures of up to $(38-40){ }^{\circ} \mathrm{C}[30]$; nevertheless, in some species, temperatures below $12{ }^{\circ} \mathrm{C}$ can cause necrosis of the stems [31]. Even if Hylocereus species are semi-epiphytes and consequently normally prefer to grow in the half-shade (conditions provided in nature by trees), certain species can grow perfectly well in the sun (H. undatus, H. costaricensis and $H$. purpusii, for example). However, very hot sun and insufficient water may lead to burning of the stems. In the Neveg Desert in Israel, the most favorable conditions for growth and fruit production were found to be $30 \%$ shade for H. polyrhizus [16]. In the French West Indies (Guadeloupe and Saint-Martin), cultivation of $H$. trigonus is only possible with about $50 \%$ shade. Excess water systematically results in the abscission of flowers and young fruits [30, 32]. Hylocereus species can adapt to different types of well-drained soil [3, 30, 33].

\subsection{Morphology and reproductive biology of $\boldsymbol{H}$. undatus and H. costaricensis}

Few studies have been published on the floral biology of $H$. undatus and H. costaricensis, the two the most widely cultivated Hylocereus species in the world. Some researchers are interested in them, in some cases to study the cultivation potential of this new fruit [1, 9], and in other cases to study the floral biology of this species that is endemic to Costa Rica and Mexico [5, 11]. 
The flowers of these two species appear under the areoles; they are large (more or less $30 \mathrm{~cm}$ ), in the shape of a funnel, and nocturnal. The ovary is located at the base of a long tube carrying the foliaceous scales to the exterior. There are numerous stamens on a slender anther stalk. The unusually large, tubular style is $20 \mathrm{~cm}$ in length and $0.5 \mathrm{~cm}$ in diameter; the stigmas have 24 slender lobes, creamy green in color [5, 34]. Floral growth does not depend on water availability, but on day length; in Vietnam, floral induction is often triggered using artificial light to increase day length. In Reunion Island, it has been demonstrated that the number of flowers obtained using artificial light at night is proportional to the distance between the receiving point and the light source [35]. The floral buds can remain in the latent stage for many weeks [5], and the beginning of flowering generally occurs after the rainy season [30].

In the southern hemisphere, $H$. undatus and $H$. costaricensis flower from November to April and, in the northern hemisphere, from May to October [3, 9, 30]. Flowering episodes are cyclic and spread out over the whole period. The number of flowering episodes or flushes depends on the species: seven to eight for $H$. costaricensis and five to six for $H$. undatus. There is a period of 3 to 4 weeks between flowering flushes [12, 30], which makes it possible to see floral buds, flowers, young fruits and mature fruits on the same plant at the same time. The periods between the appearance of floral buds (lifting of the areole) and flowering (stage 1 ), and between flower anthesis and fruit harvest (stage 2) are very short: around 15 to 20 days for the first stage and 30 days for the second stage.

In their native countries, pollination of these two allogamous species is carried out by bats at night $[7,36]$ or by a butterfly belonging to the Sphingideae family, of the genus Maduca [5]. There seems to be no major problems connected with fruit yields in the main producing countries in Latin America and Asia [3, 6, 30, 37].

Dehiscence takes place a few hours before the complete opening of the flower. Pollen is very abundant, heavy and not pow- dery. Flowers open at between 20:00 and 20:30; the stigma dominates the stamens (the position of the stigma at this stage encourages allogamy). Flowers bloom only for a day and then close (whether fertilized or not) in the morning of the day after anthesis. The following day, petals become soft and then slowly dry. The lower part of a non-fertilized flower becomes yellowish and the whole flower falls off 4 to 6 days later, while the lower part of a fertilized flower remains greenish and increases enormously in volume, indicating that the fruit has set.

In some countries (Israel, South Africa, Madagascar, Reunion Island and French West Indies), natural production of fruits from clones introduced from $H$. undatus and $H$. costaricensis is practically non-existent [31]. The auto-incompatibility [13] of the clones of these species and the absence of efficient pollinators - interspecific crossing is possible [9] - appear to be responsible for this lack of productivity. Honeybees are very attracted by the pollen of these flowers and the repeated visits of these insects can contribute to pollination [1, 9]. However, the quality of the fruits resulting from free pollination is generally lower than that of those obtained by manual cross-pollination [12]. The origin of the pollen can also influence the time lapse between pollination and harvest of the fruit (known as the phenomena of metaxenia, this was previously only observed on $H$. polyrbizus) [38].

\section{Cultivation techniques}

Pitahaya has only been domesticated for a short time and the first published references to serious cultivation practices date back only to around fifteen years [30, 37]. Little agronomic knowledge has been acquired from the traditional cultivation of these species in tropical America [24], or this knowledge has perhaps not been published. Traditional methods of cultivation have changed considerably in new production areas, as they have been adapted and improved to overcome the problems encountered there $[3,9,12,13]$. 
Figure 6.

Plantation of Hylocereus spp. with vertical support in Reunion Island.

(A color version of this figure is available at www.edpsciences.org/fruits.)

Figure 7.

Plantation (9 months old) of Hylocereus undatus with incline support in French West Indies.

(A color version of this figure is available at www.edpsciences.org/fruits.)

Figure 8.

Plantation (2 years old) of Hylocereus costaricensis with incline support in Reunion Island.

(A color version of this figure is available at www.edpsciences.org/fruits.)
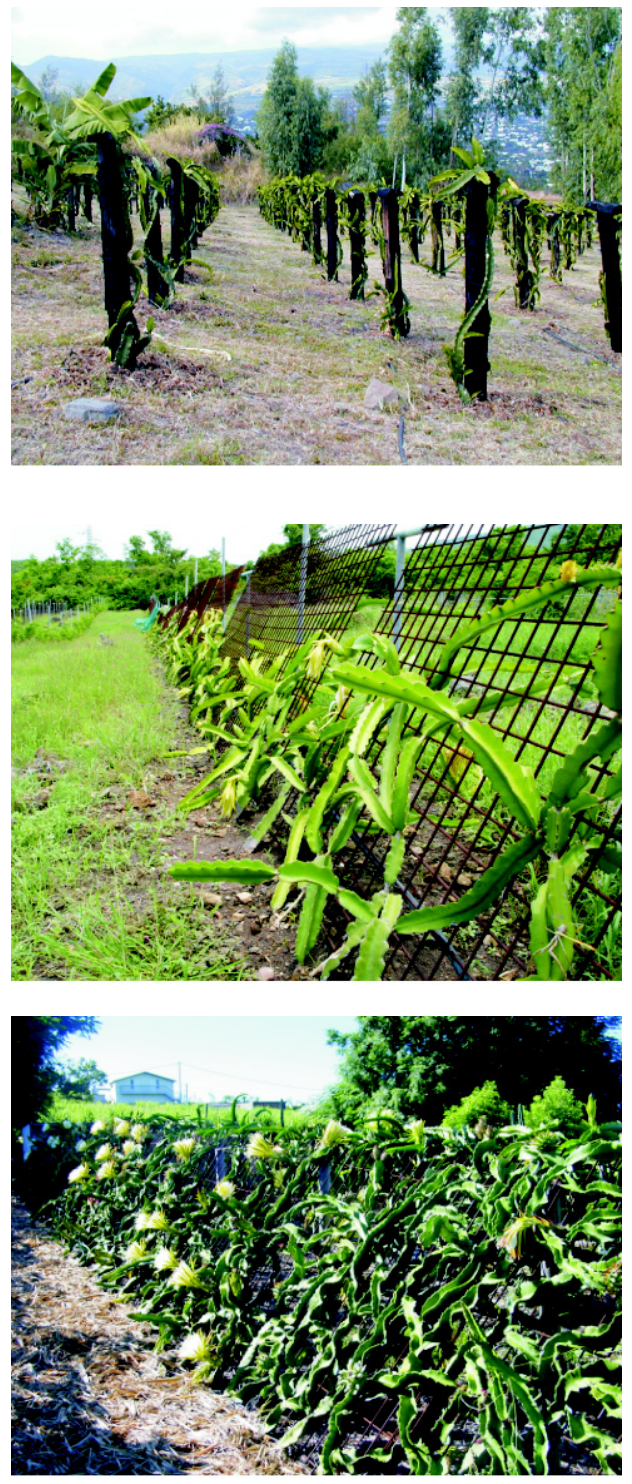

\subsection{Multiplication and planting density}

H. undatus and H. costaricensis can be multiplied naturally and very easily by cutting off the stem as soon as it touches the ground [24]. The sowing of seeds and the in vitro multiplication of young shoots of mature plants are also possible [39, 40]. However, in agriculture, multiplication by cuttings is preferable, as it allows reliable reproduction of the variety. In addition, the fruiting stage is reached more rapidly with cuttings, less than 1 year after planting, as opposed to 3 years for plants grown from seed. Finally, the robustness of these species enables cuttings to be taken directly in the field; provided cuttings are at least (50 to 70 ) $\mathrm{cm}$ in length [3] and are regularly watered in order to ensure satisfactory rooting. Given these conditions and the plant's characteristics, around $90 \%$ of the cuttings will take [39]. The distance between plants depends on the type of support used. With a vertical support (figure O), a 2-3 m distance between planting lines is required [between (2000 and 3750) cuttings $\mathrm{ha}^{-1}$ ], at a rate of three cuttings per support [3, 30].

With horizontal or inclined supports (figures 7,8$)$, the density can be much higher since the cuttings are planted every $50-75 \mathrm{~cm}$ around the production table (6500 cuttings $\cdot \mathrm{ha}^{-1}$ ) or along the inclined support (6500 cuttings $\cdot$ ha $^{-1}$ ) [39]. The height of these different types of support should be between (1.40 and 1.60) $\mathrm{m}$ for vertical supports and between ( 1 and 1.20) $\mathrm{m}$ for horizontal and inclined supports to facilitate management of the crop.

\subsection{Cultivation practices}

Pitahaya are semi-epiphytic plants, which crawl, climb and attach naturally to any natural or artificial support they meet (trees, wood or cement posts, stone walls, etc.) [34, 41] thanks to their aerial roots. Growing them flat on the ground is not recommended, firstly because it makes cultivation more difficult (pollination, harvest, etc.), secondly because contact with the ground causes damage to the vines [39]. Pitahaya are thus best grown on living or dead supports [30, 42]. Many different types of support are used, but we focus on vertical supports made of wood or cement and iron posts [3, $30,43]$, and on horizontal and inclined supports.

Plant growth is rapid and continuous, though possibly with a vegetative rest period when the climatic conditions are unfavorable (drought and very low temperatures). When vertical and horizontal supports are used, pruning is important and the stems should be selected in such a way as to force the plant to climb over the entire 
support. All lateral growth and parts of the plant facing the ground should be removed, while the main stems and branch stems are kept, except those that touch the ground. Major pruning is carried out the first year after planting. Whatever the support used, the stem must be attached to it with a clip.

The aim of maintenance pruning is to limit bunch growth and this should be carried out as early as the second year after planting. In practice, the extent of pruning depends on the type of support and its strength. For example, a 3-year-old plant weighs around $70 \mathrm{~kg}$ [39]. Even if this weight is not in itself a problem for the different types of support, bunches may not be able to withstand violent winds. Pruning consists of removing all the damaged stems from the plant in addition to those that are entangled with one another. The post-harvest pruning encourages the growth of new young shoots that will bear flowers the following year.

\subsection{Mineral nutrition and irrigation}

Yields vary as a function of the nutritive elements supplied. The pitahaya's root system is superficial and can rapidly assimilate even the smallest quantity of nutrients. Mineral and organic nutrition is particularly advantageous and, when they are combined, their effect is even more beneficial [39, 44, 45]. Even if pitahaya can survive with very low rainfall [43] - many months of drought -, when good quality fruits are required, a regular water supply is needed. Regular irrigation is important, because it enables the plant to build sufficient reserves not only to flower at the most favorable time, but also to ensure the development of the fruits. Local micro-irrigation is recommended. In addition to the efficiency of the water supplied by this system, micro-irrigation avoids uneven and excess watering that can result in the flowers and the young fruits falling off [30].

\subsection{Pollination}

The lack of genetic diversity and/or the absence of pollinating agents in certain production areas mean that manual cross-pol-

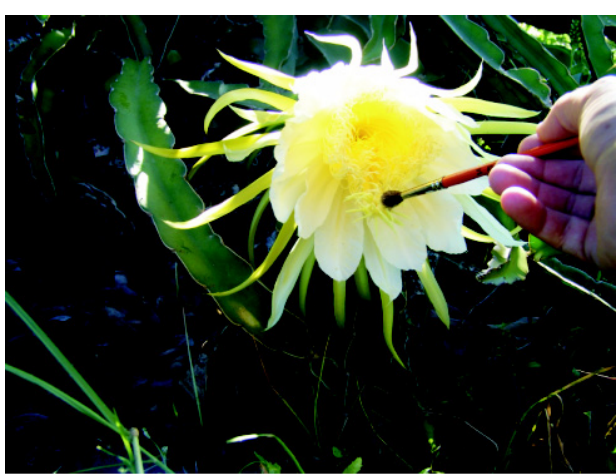

Figure 9.

Manual pollination of Hylocereus sp.

(A color version of this figure is available at

ww.edpsciences.org/fruits.) lination is needed to ensure fruit set and development [9, 11, 12]. Manual pollination (figure 9) is simple and this operation is facilitated by the floral characteristics of Hylocereus, as the different floral parts are huge. Finally, manual pollination may be carried out from before anthesis of the flower (from 4:30 P.M.) until 11:00 A.M. the next day. These manual pollinations are worth undertaking and the fruits obtained are of excellent quality [12]. Pollination is accomplished by opening the flower by pinching the bulging part. This reveals the stigmata, which are then covered with pollen with a brush. Alternatively, the anthers can be directly deposited (with minimal pressure) on the stigmata with the fingers. The pollen can be removed from a flower of a different clone (or from another species) and stored in a box until needed. The pollen removed from two flowers will be enough for around 100 pollinations with a brush. It can be stored for from (3 to 9) months at $-18{ }^{\circ} \mathrm{C}$ to $-196{ }^{\circ} \mathrm{C}$ without risk. Fruits obtained after pollination using pollen stored at $4{ }^{\circ} \mathrm{C}$ for (3 to 9) months are very small [46].

\subsection{Harvesting}

The fruit skin colors very late in the maturation stage, changing from green to red or rosy-pink ( 25 or 27 ) days (depending on the species) after anthesis [47]. Four or five days later, the fruits reach their maximal coloration. After this stage, the fruits of H. costaricensis burst without spoiling. The first harvest begins from the 18th month after the cuttings were planted; the time period between flowering and harvest is short and 
varies only slightly, from (27 to 33) days depending on the ecology $[12,30]$. The yield depends on planting density and is around (10 to 30) $\mathrm{t} \cdot \mathrm{ha}^{-1}[1,30,39]$. The absence of a peduncle makes picking difficult. The present harvesting technique of simply twisting the fruit very often injures the skin, and secateurs should consequently be used. The fruits are not very fragile, but to ensure a good quality product certain precautions should be taken; for example, careful handling during processing and storage, especially for $H$. costaricensis whose foliated scales are brittle.

\section{Pests and diseases}

Few pests have been recorded on Hylocereus. Ants belonging to the genera Atta [30] and Solenopsis [3, 39] can cause major damage to the plants as well as to the flowers and fruits. Cotinus mutabilis perforates the stem and Leptoglossus zonatus sucks the sap, leaving stains and some deformation [30]. Different species of aphids and scales have also been observed on fruits and flowers. Rats and birds can cause serious damage, mainly to flowers [39] and fruits [3], but also to ripe fruits. The activity of bees (Apis mellifera) can make manual pollination difficult, but it must nevertheless be accomplished [12]. In fact, bees can be extremely efficient and, after only a few hours of activity, they will have harvested all the pollen. The pollen must thus be collected before the bees arrive and manual pollination carried out the next morning as soon as the bees have left the plantation. Different fungal (Gloeosporium agaves, Macssonina agaves, Dothiorella sp. and Botryosphaeria dothidea), viral (Cactus virus X), and bacterial (Xanthomonas sp. and Erwinia sp.) diseases are also reported in the literature and can have major consequences [3, 30, 34, 48-50].

\section{Physico-chemical composition of fruits}

The edible part of the fruit consists of the mesocarp, which has a mucilaginous texture with thousands of small soft seeds distrib- uted homogeneously throughout the flesh. Fruit pulp represents from (60 to 80 ) $\%$ of mature fruit weight in most Hylocereus species [28, 47]. Juice yield without seeds is much lower, representing only 55\% in some pitahaya cultivars.

The mesocarp contains 82-88\% water with a typical total soluble solids content between ( 7 and 11) $\mathrm{g} \cdot \mathrm{L}^{-1}$ in mature fruit [28, $47,51]$.

According to some authors, Hylocereus species with white flesh have higher soluble solids contents than those with red flesh fruits [52], and the distribution of soluble solids in the fruit flesh is not homogeneous, the core part being richer in sugars than the peripheral part. The soluble solids consist mainly of reducing sugars, and more specifically glucose and fructose, with contents ranging from (30 to 55 ) $\mathrm{g} \cdot \mathrm{L}^{-1}$ and ( 4 to 20) $\mathrm{g} \cdot \mathrm{L}^{-1}$, respectively, depending on variety and cultivar (table I). Various authors, using HPLC methods for the determination of sugars, have not detected the presence of sucrose [28, 51], but, using enzymatic methods, other authors found that sucrose accounts for (2.8 to 7.5$) \%$ of total sugars [52].

Acidity of the flesh is generally low, between (2.4 and 3.4) $\mathrm{g} \cdot \mathrm{L}^{-1}$, which results in a high sugar-to-acid ratio, giving a poor sensory quality when juice is consumed alone. Traditionally, sensory quality is considerably improved by blending pure pitahaya juice with a more acid fruit juice; lemon, for example. The main organic acids present in pitahaya juice are citric acid and L-lactic acid [51].

Protein content varies considerably depending on the authors [from (0.3 to $1.5) \%$; these differences may be due to the methodologies applied, or because of possible interference from betalain, the nitrogen-containing pigment responsible for the red color. The main amino acid present in pitahaya juice appears to be proline with a remarkably high content of (1.1 to 1.6$) \mathrm{g} \cdot \mathrm{L}^{-1}$ of juice [51, 53]. Mineral content is relatively high with potassium, the most prevalent ion, followed by magnesium and calcium (table I).

Hylocereus species appear to be surprisingly poor in vitamin $\mathrm{C}$ with less than $11 \mathrm{mg} \cdot \mathrm{L}^{-1}$, while other cactus species, for example, prickly pear, have a much higher 
Table I.

Main physico-chemical characteristics of Hylocereus sp. according to the literature ([28]: Vaillant et al., 2005; [39]: Le Bellec, 2003; [51]: Stintzing et al., 2003).

\begin{tabular}{|c|c|c|c|c|c|c|c|c|c|}
\hline Publication & $\mathrm{pH}$-value & $\begin{array}{l}\text { Dry matter } \\
(\%)\end{array}$ & $\begin{array}{c}\text { Total } \\
\text { titratable acids } \\
\left(\mathrm{g} \cdot \mathrm{L}^{-1}\right)\end{array}$ & $\begin{array}{c}\text { Total } \\
\text { soluble solids } \\
\text { ('Brix) }\end{array}$ & Protein content & Lipid & $\begin{array}{l}\text { Glucose } \\
\left(g \cdot \mathrm{L}^{-1}\right)\end{array}$ & Fructose & Potassium \\
\hline$[28]^{\star \star}$ & $4.3-4.7$ & $12 \pm 1$ & $2.4-2.5$ & $7.1-10.7$ & - & - & $30-54$ & $4-7 \mid$ & - \\
\hline [39] & - & - & - & $3.05^{\star \star} / 5.7^{\star}$ & $1.2^{\star} / 1.25^{\star \star}$ & $\begin{array}{l}1.17^{\star} / \\
1.43^{\star \star}\end{array}$ & - & - & - \\
\hline [51] & $4.4-4.6$ & - & $3.3-3.4$ & - & $0.3-0.4$ & - & $46^{\star} / 55^{\star \star}$ & $18^{\star} / 19^{\star \star}$ & $3.2^{\star \star} / 4^{\star}$ \\
\hline \multirow[t]{2}{*}{ Publication } & \multirow{2}{*}{\multicolumn{2}{|c|}{ Sodium }} & Magnesium & \multirow{2}{*}{\multicolumn{2}{|c|}{$\begin{array}{l}\text { Calcium } \\
\left(\mathrm{mg} \cdot \mathrm{L}^{-1}\right)\end{array}$}} & \multirow{2}{*}{\multicolumn{2}{|c|}{ L-ascorbic acid }} & \multirow{2}{*}{\multicolumn{2}{|c|}{$\begin{array}{c}\text { Energy } \\
\left(\mathrm{kcal} \cdot 100 \mathrm{~g}^{-1}\right)\end{array}$}} \\
\hline & & & & & & & & & \\
\hline$[28]^{\star \star}$ & \multicolumn{2}{|r|}{-} & - & \multirow{2}{*}{\multicolumn{2}{|c|}{ - }} & \multicolumn{2}{|c|}{$11 \pm 0.5$} & \multicolumn{2}{|c|}{ Not determined } \\
\hline [39] & \multirow{2}{*}{\multicolumn{2}{|c|}{$\begin{array}{c}- \\
33^{*} / 733^{\star *}\end{array}$}} & - & & & \multicolumn{2}{|l|}{-} & \multicolumn{2}{|c|}{$37.9^{\star} / 41.7^{\star \star}$} \\
\hline$[51]$ & & & $265^{\star} / 312^{\star \star}$ & \multicolumn{2}{|c|}{$23^{\star \star} / 30^{\star}$} & Jot determ & ed & \multicolumn{2}{|c|}{-} \\
\hline
\end{tabular}

vitamin $\mathrm{C}$ content comparable with that of citrus. Other vitamins may be present, but they have not been reported.

Other micronutrients appear to be present in greater quantities in pitahaya, especially in the species with red-purple flesh. The red color is due to the presence of betalains, pigments that replace anthocyanins in fruitbearing plants belonging to most Caryophyllales families [51, 54]. Betalains are water-soluble pigments that comprise redpurple betacyanin and yellow betaxanthins, and they are an immonium conjugate of betalamic acid with cyclo-dopa and amino acids or amines, respectively [54]. In contrast to red beet and other cactus fruits, red-purple pitahaya (Hylocereus polyrhizus) is a pure source of betacyanin, as betaxanthins are totally absent [55], which explains the deep glowing red-purple color of the flesh. At least ten betacyanin compounds have been identified in pitahaya $H$. polyrbizus, but all pigments display the same red color with an absorbance peak around $536 \mathrm{~nm}$ [55]. Betalains are of commercial interest not only for food coloring, but also for their anti-oxidant properties for protection against certain oxidative stress-related disorders [51, 54]. Pitahaya juice has a high antiradical activity (around $10 \mu \mathrm{mol}$ Trolox equivalent assessed by the ORAC method with fluorescein, a value very similar to beetroot [28]). Pitahaya may also contain other phenolic compounds [ 6 to 7.5$) \mu \mathrm{mol}$ equivalent of galic acid $\left.\cdot \mathrm{g}^{-1}\right]$ but characterization has not been reported yet.

Polysaccharides present in the pitahaya mesocarp have not been characterized yet. They are responsible for the mucilaginous texture and the viscosity of the juice. Recent findings (not published) show that polysaccharides may represent around $1 \%$ of the weight of the mesocarp without seeds, and that they are mainly hemicelluloses and, in much lower proportion, cellulose and pectin. Characterization of the hemicelluloses and neutral sugars present in the pitahaya mesocarp has not been published yet.

\section{Post-harvest}

Pitahaya fruit can be harvested between ( 25 and 30) days after anthesis, depending on the variety, when the peel turns fully red [ 47 , 56]. Once this stage is reached, fruits can be stored for 3-4 days at ambient temperature [30], and $1-2$ weeks at $20^{\circ} \mathrm{C}$ or $14^{\circ} \mathrm{C}$, respectively [47]. Pitahaya is not a climacteric fruit and no production peak of ethylene or of $\mathrm{CO}_{2}$ 
has been observed; its physico-chemical characteristics and sensory properties start to decline slightly after harvesting [47]. Fruits harvested 1-2 days before full coloration of the skin can be preserved for up to 1 month at $10{ }^{\circ} \mathrm{C}$ without any observed decrease in global quality [39]. Harvesting pitahaya fruits at 5-8 days after full coloration slightly reduces their storage life, although the fruit sensorial properties are said to be improved, giving a sweeter taste and a blackberry flavor in the case of red pitahaya (H. costaricensis). Studies on the physiology of respiration and biochemistry of pitahaya fruit during storage have not yet been published.

\section{Processing}

Processing pitahaya fruit into juice is a difficult task on an industrial scale as no specialized equipment for extracting such a juice is currently available. Presently, juice extraction is done manually by halving the fruit and extracting the pulp with a spoon. The pulp behaves as a non-Newtonian fluid with high apparent viscosity and it is suspected of having a strong shear thinning behavior like other mucilaginous material from cactus fruits [57]. This makes it very difficult to remove the thousands of small soft seeds (diameter $<1 \mathrm{~mm}$ ) by simple sieving, and juice without seeds can only be obtained by drastically reducing juice yield. Consequently, the juice is usually frozen with the seeds and sold to buyers in this way. Nonetheless, the presence of seeds is a major constraint to the development of a pitahaya juice industry, mainly because it is currently impossible to offer a competitive juice concentrate. Several commercial enzyme preparations, containing mainly pectolytic and cellulolytic activity, have already been tested by industry, but viscosity reduction was surprisingly low and the use of enzymes has more or less been abandoned, proving that pectin and cellulose may not be the main factors responsible for the rheological behavior of the juice. The characterization of cell-wall polysaccharides and of the mucilage of pitahaya is a precondition for the development of more suitable enzymatic preparations, but it has not yet been published.
Once the juice is obtained, it will withstand brief thermal treatments. The color stability of betalains from pitahaya is highest at $\mathrm{pH} 5$ [58], precisely the $\mathrm{pH}$ of the juice. Nonetheless, color stability is very similar to that of beetroot and it is consequently compatible with uses in most foodstuffs at more acidic $\mathrm{pH}$ [28]. A recent investigation showed that pigments from purple pitahaya display higher stability than-earlier investigations on betalains suggested [59]. During a typical pasteurization treatment, color losses were less than 10\% [28] and they can be slightly improved if pitahaya juice is deaerated previously. Nonetheless, during severe thermal treatment, losses are likely to be much greater, which explains why products such as jams, jellies and other sweet products are not normally produced, but ice-creams [60] and other dairy products are widely marketed. To avoid high color losses, single red pitahaya juice is generally supplied to the international market without being pasteurized and frozen. It then undergoes only one pasteurization process during the production of final products.

The peel could also be used for the recovery of colored pigments, as betacyanins are present in considerable amounts [61]. Nevertheless, extraction may be complex and not competitive with respect to other betalain sources unless the recovery of a thickening agent of commercial interest could be done simultaneously. No work on this issue has been reported yet and more research is needed to characterize pitahaya mucilage in the same way as has been done for Opuntia spp., which appeared recently to be of high commercial interest [57].

Pitahaya products may therefore combine coloring and thickening properties with functional properties, such as anti-oxidant capacity and dietary fiber. Nevertheless, food products derived from pitahaya are still seldom seen on the market and more research must be done to improve commercial opportunities.

\section{European market}

Pitahaya are widely consumed in Asia, but they were unknown in the European Union 
until the mid-1990s. The fruit is still a niche product, but imports have increased considerably in the last two years and pitahaya now has its place in the displays of retailers devoted to rare exotic fruits. The range of supplier countries is growing rapidly. Israel, with a major cost price advantage thanks to sea transport, competes with Asian suppliers during the second half of the year.

The fruit attracts two different market segments

- Asian customers purchase it quite regularly, with a peak at the Chinese New Year. On this occasion, it is not usually bought for its taste, but for its fine appearance as it is displayed as an offering to ancestors. The greatest demand is for large fruits. Some importers supply 10-kg boxes for Asian supermarkets in addition to boxes weighing (2 to 4) $\mathrm{kg}$.

- European customer demand-especially supermarkets - is very irregular, with a peak mainly at Christmas, when exotic fruits are promoted. Small fruits in boxes weighing (2 to 4$) \mathrm{kg}$ are the most commonly purchased.

There is no specific customs code for the fruit, listed in the 'passion fruit, carambola and pitahaya' group (code 08109040). However, imports can be estimated since the countries operating on the international pitahaya market export little or no carambola or passion fruit. The quantities shipped to the EU in 2004 were marginal at about $800 \mathrm{t}$. In comparison, papaya imports totaled $34000 \mathrm{t}$ and pineapple imports reached nearly $390000 \mathrm{t}$ in the same year.

Nevertheless, the market is considerably increasing and has been particularly rapid in the last two years (quantities doubled between 2002 and 2004). Vietnam, the first country to ship the fruit to the EU, is not the only supplier country responsible for this increase and imports from Vietnam stagnated in 2004. Thailand which, like Vietnam, produces all year round, has emerged since 2003. Its market share increased from less than $10 \%$ in 2001 to $17 \%$ in 2004 . Thailand has an advantage over Vietnam in the cost of airfreight, a key factor in competitiveness. Exporters can benefit from reductions for quantity by grouping pitahaya with other exotic fruits exported to Europe such as rambutan and mangosteen. Furthermore, Thai airlines accept payment in local currency and not dollars, which is the case in Vietnam. Finally, the Thai government subsidizes transport, again in contrast to Vietnam.

However, in 2004, a Mediterranean country was the leading supplier of this typically Asian fruit. In spite of having a shorter growing season than its competitors, Israel has succeeded thanks to a major competitive feature, once again connected with logistics. Unlike the fruit from Asian countries, most goods are shipped by sea from Israel. Ashod is not very far from Marseilles and the Israelis are recognized for the quality of their sea transport (new vessels built specifically for carrying fresh produce). Israeli operators can thus sell at more competitive prices than operators in other supplier countries and, for a period of only 3.5 months, they sell comparatively large volumes that often vary considerably from one week to the next. The average price has fallen considerably since 2003, especially in Germany, the leading EU market. During the period when quantities reach their highest point (generally in September/October), prices fall to levels that do not cover the transport cost of pitahaya from Asia (especially from Vietnam). The market structure changes radically at this time of year, and certain supplier countries are elbowed out. The quantities sold for marketing in France are more limited and this market has been less affected by these changes so far.

Importers' opinions differ with regard to the growth potential of the pitahaya market. The cost of airfreight has a negative influence on retail prices for most of the year and is clearly a limiting factor, but the example of Israel and the German market shows that there is substantial margin for growth. Thanks to more affordable prices for consumers, in 3.5 months (and without the support of a promotion period) Israel sells $70 \%$ of the quantities marketed by Asian suppliers in a whole year. The Israeli sector should continue to develop and increase supplies to markets in southern Europe. Market development will still be governed by the cost of airfreight for Asian suppliers, especially during the very competitive period in September and October. 


\section{Conclusion}

Our bibliographical study gives an initial evaluation of the advantages and disadvantages of growing pitahaya.

Commercially, pitahayas appear to have numerous selling points; the fruits are attractive in shape and color, and they have very good internal properties of high interest for the food industry. The red flesh species are additionally rich in betalains, meeting the increasing trade interest for antioxidant products and natural food colorant. Pitahaya fruits are not very fragile and are easy to keep fresh. All these qualities allow different possible uses to be envisaged: as fresh fruit or processed.

As far as agronomy is concerned, these species are generally hardy, easy to multiply and cultivate. In general, they produce fruits quickly and few diseases and pests are encountered at the present time. The fact these species grow like lianas means supports are necessary and sometimes shade, depending on the ecology. In addition to the high cost of the support, labor is also needed if manual pollination is performed to ensure high-quality products.

Finally, our review of the literature also highlights the fact that the interest shown in these species is recent and, for this reason, more detailed knowledge of these plants is required. The agronomy, genetics and the technological qualities of this group of species that are still relatively unknown in most parts of the world merit further research.

\section{References}

[1] Mizrahi Y., Nerd A., Nobel P.S., Cacti as crop, Hortic. Rev. 18 (1997) 291-320.

[2] Imbert E., La pitahaya, un marché en devenir, Fruitrop 80 (2001) 13.

[3] N'Guyen V.K., Floral induction study of dragon fruit crop (Hylocereus undatus) by using chemicals, Univ. Agric. Forest., Fac. Agron., Hô Chi Minh-ville, Vietnam, 1996, $54 \mathrm{p}$.

[4] De Dios H.C., Distribución geográfica de las pitahaya (Hylocereus) en la República Mexicana, Cact. Suc. Mex. 49 (2004) 4-23.
[5] Daubresse Balayer M., Le pitahaya, Fruits Oubliés 1 (1999) 15-17.

[6] Jacobs D., Pitaya, Hylocereus undatus, a potential new crop for Australia, Rare Fruit Counc. Aust. Inc. Newsl. 107 (1998) 3-7.

[7] Nerd A., Mizrahi Y., Reproductive biology of cactus fruit crops, Hortic. Rev. 18 (1997) 321-346.

[8] Le Bellec F., Judith R.C., La pitaya (Hylocereus sp.) en culture de diversification à l'île de la Réunion: stratégie d'accompagnement de son développement, Fruits 57 (2002) 219-229.

[9] Weiss J., Nerd A., Mizrahi Y., Flowering behavior and pollination requirements in climbing cacti with fruit crop potential, HortScience 29 (1994)1487-1492.

[10] Lichtenzveig J., Abbo S., Nerd A., Tel-Zur N., Mizrahi Y., Cytology and mating systems in the climbing cacti Hylocereus and Selenicereus, Am. J. Bot. 87 (2000) 1058-1065.

[11] Castillo R.M., Livera M.M., Alicia E., Brechú F., Márquez-Guzmán J., Compatibilidad sexual entre dos tipos de Hylocereus (Cactaceae), Rev. Bio. Trop. 51 (2003) 699-706.

[12] Le Bellec F., Pollinisation et fécondation d'Hylocereus undatus et d' $H$. costaricensis à l'île de la Réunion, Fruits 59 (2004) 411-422.

[13] Raveh E., Weiss J., Nerd A., Mizrahi Y., Pitayas (genus Hylocereus) new fruit crop for the Negev Desert of Israel in: Janick J., Simon J.E. (Eds.), New crops, Wiley, New-York, USA, 1993, 491-495.

[14] Ortiz-Hernández Y.D., Livera-Muñoz M., Carrillo-Salazar J.A., Asimilacin de $\mathrm{CO}_{2}$ en tallos jovenes de pitahaya (Hylocereus undatus), Rev. Fitotec. Mex. 19 (1996) 31-41.

[15] Raveh E., Nerd A., Mizrahi Y., Responses of climbing cacti to different levels of shade and to carbon dioxide enrichment, Acta Hortic. 434 (1996) 271-277.

[16] Raveh E., Nerd A., Mizrahi Y., Responses of two hemi epiphytic fruit crop cacti to different degrees of shade, Sci. Hortic. 73 (1998) 151-164.

[17] Ortiz-Hernández Y.D., Livera-Muñoz. M., Carrillo-Salazar J.A., Asimilación de $\mathrm{CO}_{2}$ por la pitahaya Hylocereus undatus en conditiones de campo, Agrocienca 33 (1999) 165169.

[18] Nerd A., Sitrit Y., Kaushik R.A., Mizrahi Y., High summer temperatures inhibit flowering in vine pitaya crops (Hylocereus spp.), Sci. Hortic. 96 (2002) 343-350. 
[19] Nobel P.S., De la Barrera E., Stem water relations and net $\mathrm{CO}_{2}$ uptake for a hemi epiphytic cactus during short-term drought, Environ. Exp. Bot. 48 (2002) 129-137.

[20] Nobel P.S., De la Barrera E., Beilman D.W., Doherty J.H., Zutta B.R., Temperature limitations for cultivation of edible cacti in California, Madrono 49 (2002) 228-236.

[21] Nobel P.S., De la Barrera E., $\mathrm{CO}_{2}$ uptake by the cultivated hemi epiphytic cactus, Hylocereus undatus, Ann. Appl. Biol. 144 (2004) 1-18.

[22] Fournet J., Flore illustrée des phanérogames de Guadeloupe et de Martinique, Tome 1, Famille des Cactaceae, Inra-Cirad-Gondwana, Paris, France, 2002, pp. 224-240.

[23] Spichiger R.E., Savolainen V.V., Figeat M., Botanique systématique des plantes à fleurs - une approche phylogénétique nouvelle des angiospermes des régions tempérées et tropicales, Presses Polytech. Univ. Romand., Lausanne, Suisse, 2000, 372 p.

[24] Fouqué A., Espèces fruitières d'Amérique tropicale, famille des Cactaceae, IFAC, Paris, France, 1969, pp. 25-34.

[25] Britton N.L., Rose J.N., Descriptions and illustrations of plants of the cactus family, Vol. I and II, Dover Publ., Inc., New York, USA, 1963, pp. 183-195.

[26] Tel-Zur N., Abbo S., Bar-Zvi D., Mizrahi Y., Clone identification and genetic relationship among vine cacti from the genera Hylocereus and Selenicereus based on RAPD analysis, Sci. Hortic. 100 (2004) 279-289.

[27] Innes C., Glass C., L'encyclopédie illustrée des cactus, Bordas, Paris, France, 1992, pp. 139-140.

[28] Vaillant F., Perez A., Davila I., Dornier M., Reynes M., Colorant and antioxidant properties of red pitahaya (Hylocereus sp.), Fruits 60 (2005) 1-7.

[29] Backeberg C., Cactus lexicon, Blandford Press Ltd., Dorset, England, 1976, pp. 213215.

[30] Barbeau G., La pitahaya rouge, un nouveau fruit exotique, Fruits 45 (1990) 141-174.

[31] Erwin J.E., Temperature and photoperiod affect grafted cactus scion necrosis, HortTechnology 6 (1996) 393-397.

[32] Le Bellec F., Renard V., Le grand livre des fruits tropicaux, Orphie, Saint-Denis, France, 1997, $180 \mathrm{p}$.

[33] Bárcenas P., Efecto de tres substratos en ele enrizamiento y desarrollo de pitahaya
(Hylocereus undatus), Proc. Interamer. Soc. Trop. Hort. 38 (1994) 120-121.

[34] Luders L., The pitaya or dragon fruit, Prim. Ind. Fish., North. Territ. Aust., 1999, p. 778.

[35] Lavigne C., Valorisation d'espèces et variétés fruitières tropicales et subtropicales, synchronisation des floraisons de la pitaya, Rapp. activ. Cirad Réunion, Saint-Pierre, France, 2003, pp. 2-3.

[36] Herrera G.L., Martinez Del Rio C., Pollen digestion by new world bats: effects of processing time and feeding habits, Ecology 79 (1998) 2828-2838.

[37] Becerra Ochoa L.A., El cultivo de la pitaya, Fed. Nac. café. Coloma., 6th ed., Manizales, Colombia, $20 \mathrm{p}$.

[38] Mizrahi Y., Mouyal J., Nerd A., Sitrit Y., Metaxenia in the vine cacti Hylocereus polyrhizus and Selenicereus spp., Ann. Bot. 93 (2004) 469-472.

[39] Le Bellec F., La pitaya (Hylocereus sp.) en culture de diversification à l'île de la Réunion, Inst. Natl. Hortic. (INH), Mém., Angers, France, 2003, 55 p.

[40] Yassen M.Y., Micropropagation of pitaya (Hylocereus undatus Britton \& Rose), In Vitro Cell. Dev. Biol.-Plant 38 (2002) 427-429.

[41] Rondón J.A., Cactáceas epifitas y trepadoras de la reserva forestal de Caparo, estado Barinas, Venezuela, Rev. For. Venez. 42 (1998) 119-129.

[42] De Dios H.C., Castillo Martinez R., Soportes vivos para pithaya (Hylocereus spp.) en sistemas agroforestales, Agrofor. Am. 7 (2000) 21-25.

[43] Mizrahi Y., Nerd A., Climbing and columnar cacti: new arid land fruit crop, in: Janick J. (Ed.), Perspectives on new crops and new use, ASHS Press, Alexandria, VA, USA, 1999, 358-366.

[44] Du Prez R.J., The pitaya - a cactus fruit with potential, Neltropika August (1997) 28-29.

[45] López Turcios O., Guido M.A., Evaluación de dosis de nitrógeno y fósforo en el cultivo de pitahaya (Hylocereus undatus), Agron. Mesoam. 9 (1998) 66-71.

[46] Metz C., Nerd A., Mizrahi Y., Viability of pollen of two fruit crop cacti of the genus Hylocereus is affected by temperature and duration of storage, HortScience 35 (2000) 22-24.

[47] Nerd A., Guttman F., Mizrahi Y., Ripening and postharvest behaviour of fruits of two Hylocereus species (Cactaceae), Postharvest Biol. Technol. 17 (1999) 39-45. 
[48] Boyle T.H., Mayhew D.E., Wiens A.L., Virus in cactus grafting stocks, Cactus Succul. J. (USA) 69 (1997) 40-41.

[49] Valencia-Botin A.J., Sandoval-Islas J.S., Cardenas-Soriano E., Michailides T.J., Rendon-Sanchez G., Botryosphaeria dothidea causing stem spots on Hylocereus undatus in Mexico, Plant Pathol. 52 (2003) 803.

[50] Liou M.R., Chen Y.R., Liou R.F., Complete nucleotide sequence and genome organization of a Cactus virus $X$ strain from Hylocereus undatus (Cactaceae), Arch. Virol. 149 (2004) 1037-1043.

[51] Stintzing F.C., Schieber A., Carle R., Evaluation of colour properties and chemical quality parameters of cactus juices, Eur. Food Res. Technol. 216 (2003) 303-311.

[52] Wu M.C., Chen C.S., Variation of sugar content in various parts of pitahaya fruit, Proc. Fla. State Hortic. Soc. 110 (1997), 225-227.

[53] Stintzing F.C., Schieber A., Carle R., Phytochemical and nutritional significance of cactus pear, Eur. Food Res. Technol. 212 (2001) 396-407.

[54] Strack D., Vogt T., Schliemann W., Recent advances in betalain research, Phytochemistry 62 (2003) 247-269.

[55] Stintzing F.C., Schieber A., Carle R., Betacyanins in fruits from red-purple pitaya,
Hylocereus polyrhizus (Weber) Britton \& Rose, Food Chem. 77 (2002) 101-106.

[56] Le-Van T., Nguyen N., Nguyen-Duy D., HaThi-Thanh H., Dragon fruit quality and storage life: effect of harvesting time, use of plant growth regulators and modified atmosphere packaging, Acta Hortic. 575 (2002) 611-621.

[57] Cardenas A., Higuera-Ciapara I., Goycoolea F.M., Rheology and aggregation of cactus (Opuntia ficus-indica) mucilage in solution, $\mathrm{J}$. Prof. Assoc. Cactus Dev. (1997) 152-157.

[58] Stintzing F.C., Klaiber I., Beifuss U., Carle R., Structural investigations on betacyanin pigments by LC NMR and 2D NMR spectroscopy, Phytochemistry 65 (2004) 415-422.

[59] Herbach K.M., Stintzing F.C., Carle R., Thermal degradation of betacyanins in juices from purple pitaya [Hylocereus polyrhizus (Weber) Britton \& Rose] monitored by highperformance liquid chromatography-tandem mass spectrometric analyses, Eur. Food Res. Technol. 219 (2004) 377-385.

[60] Xiang G., Rui W., Study on the producing of pitaya ice cream, China Dairy Ind. 32 (2004) 9-11.

[61] Zhijian D., Xin Y., Studies on the stability of red pigment in Hylocereus undatus fruit, J. South China Agric. Univ. 24 (2003) 79-83.

\section{Pitahayas (Hylocereus spp.): frutas nuevas y un mercado con perspectivas} de desarrollo.

Resumen - Introducción. Prácticamente desconocido a mediados de la década de 1990, las pitahayas (Hylocereus spp.) hacen ya parte del mercado Europeo y se pueden observar en los anaqueles dedicados a frutas exóticas. Sin embargo, las diferentes especies son poco conocidas. Los objetivos de nuestro trabajo consideran el estudio exhaustivo de la bibliografía disponible con complementos que incluyen trabajos agronómicos no publicados. Conocimiento de Hylocereus. El estudio hace una presentación del origen, la botánica, la morfología y la biología floral de las principales especies cultivadas del genero Hylocereus y propone una clave para su determinación. Técnicas culturales. Las diferentes labores culturales conocidas son presentadas: técnicas de multiplicación, conducción agronómica (tutores, poda, fertilización, riego, etc.), polinización, cosecha, etc. Las principales enfermedades y plagas son citadas. Composición físico-química del fruto. Este trabajo presenta una síntesis de los diferentes estudios realizados sobre la pitahaya: composición físico-química, micronutrientes y colorante. Pos-cosecha y transformación. La vida de fruto post-cosecha (conservación, almacenamiento, etc.) son presentados así como las diferentes posibilidades de procesamiento. Mercado Europeo. Se analizó el mercado europeo para las diferentes especies de hylocereus cultivadas (volúmenes importados, procedencia, etc.) así como las perspectivas de evolución. Conclusión. Nuestra síntesis bibliografía muestra que el interés hacia las pitahayas es reciente y, por esta razón, es necesario profundizar aún más los conocimientos sobre estas especies (agronomía, genética, tecnología).

zona tropical / zona subtropical / Hylocereus / botánica / agronomía / composición quimíca / almacenamiento / tecnología postcosecha / unión europea / mercados 